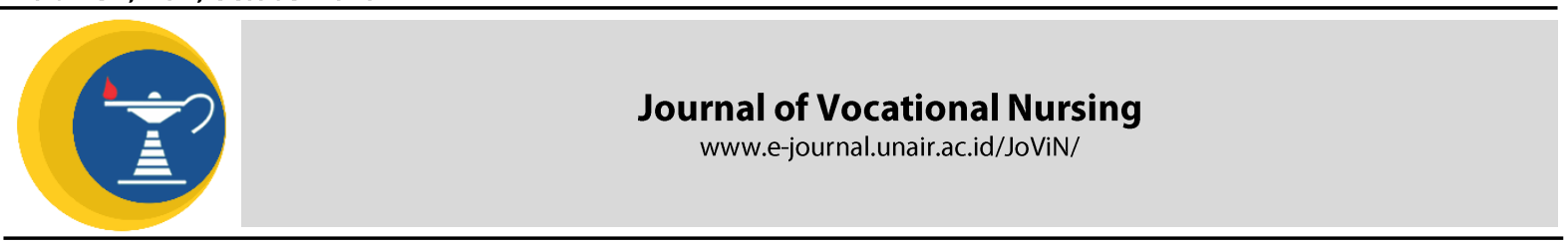

\title{
MENTAL STATUS WITH SOCIAL INTERACTION CAPACITY IN THE ELDERLY AT SUKODADI COMMUNITY HEALTH CENTER, LAMONGAN DISTRICT
}

\author{
Khotibul Umam¹, Joko Susanto², Tantri Tristiana Dewi³ ${ }^{3}$ and Endah Sri Wijayanti ${ }^{4}$, \\ Lailatul Fadliyah ${ }^{5}$ \\ 1,2,4,5 DIII Nursing Study Program, Departement of Health, Faculty of Vocational Studies, Universitas Airlangga \\ ${ }^{3}$ Akademi Keperawatan Pemkab Lamongan
}

Research Report

\begin{abstract}
Introduction: In the human life cycle there is growth and development either physically and mentally. In the elderly phase there are both physical and mental changes due to the degenerative process, leading to limitation in having physical activities, remembering things and speaking. This limitation affects social interaction with others which tends to decline and become passive. Decreasing social interaction of the elderly can cause the feeling of isolation, being useless and lead them to seclusion, because there is no emotional channeling through socializing. The purpose of this study was to identify the association between mental status and Social Interaction Capacity among the elderly at Sukodadi Community Health Center, Lamongan District. Methods: This quantitative study used correlational study and cross sectional design. Data were obtained from Short Portable Mental Status Questionnaire and social interaction capacity questionnaire. Samples consisted of 47 respondents, taken with consecutive sampling technique. Data analysis used Spearman test. Results: The majority of respondents $(44,7 \%)$ had medium intellectual damage and the majority $(51,1 \%)$ had medium social interaction capacity. The result of Spearman rho test showed $p=0,024$ and $r=0,328$ which meant that there was association between mental status and social interaction capacity at medium strength and positive correlation direction. Conclusion: There was association between mental status and social interaction capacity of the elderly at Sukodadi Community Health Center, Lamongan District.
\end{abstract}

\section{ARTICLE INFO}

Recived 17 October 2020

Accepted 25 October 2020

Online 29 October 2020

*Correspondence:

Khotibul Umam

*Email:

khotibul.umam@

vokasi.unair.ac.id

\section{Keywords:}

Mental Status, Social Interaction capacity, Elderly

\section{INTRODUCTION}

Increasing life expectancy in almost all countries in the world has resulted in an increase in the number of elderly people (elderly) and a demographic transition towards the elderly population (Depkes RI, 2010). In Indonesia in 2000 it is estimated that the number of elderly people will increase to $9.99 \%$ of the total population of Indonesia with a life expectancy of 65-70 years and in 2020 it will increase to $11.09 \%$ with a life expectancy of 70-75 years (Muhith and Siyoto, 2016). Currently it is estimated that there are 500 million elderly people in the world with an average age of 60 years and it is estimated that by 2025 it will reach 1.2 billion. According to the 1990 population census in Indonesia, the population is 179.3 million, of which there are 10 million people
(5.5\%) people aged 60 years and over of the total population and by 2020 it is estimated to increase 3 times to +29 million people. (11.4\%) of the total population (Wilianarti, 2018).

The consequence of increasing the proportion of elderly raises problems that require serious handling. The problems that occur are not only caused by population factors, but also by biological, socio-cultural, economic and psychological factors, due to physical, biological and mental deterioration that cannot be separated from social, cultural and economic problems (Rautio, Heikkinen and Heikkinen, 2015). The increase in the number of elderly people will affect health conditions. The biggest health problem in elderly varies between developed and 
developing countries and contributes to the health status of the elderly (Depkes RI, 2010).

One of the health status of the elderly is functional status, which is a person's ability to carry out their daily activities in a healthy manner. This concept is integrated into three main domains, namely biological, psychological and social functions. These three components are interrelated and contribute to health behavior and function. One of the psychological components is mental status which includes attention, perception, thinking, knowledge and memory (Stanley, 2012).

Factors that are thought to be related to mental status are disease, environment and behavior, namely stress, physical activity and social contact, as well as sociodemographic factors such as age, education, work and living alone (Lueckenotte, 2013). Several studies reported that in the elderly who have difficulty doing physical movement or are not active, there will be differences in mental status. The result of the many changes due to aging will require the elderly to be able to adjust. If the elderly's adjustment is hampered, conditions will arise that can interfere with their physical and mental state (Gallo et al., 2012).

As a result of decreased mental health in the elderly, will have an effect on shifting roles in society and in the family, resulting in the elderly feeling alienated, isolated and feeling useless, because there is no emotional channeling through socializing. This condition causes social interaction to decline both in quality and quantity (Kaplan, Sadock and Grebb, 2014).

Ideally, the elderly are expected to remain productive and not dependent on others by maintaining and improving their lives according to their abilities, so that the elderly have excellent physical and mental conditions (Stanley, 2012). A good lifestyle will cause the elderly to continue to have the strength and enthusiasm for activities so that self-esteem is still maintained and in the end the elderly will get peace and life satisfaction in old age which includes service satisfaction, activities and interactions.

\section{MATERIALS AND METHODS}

This research is a quantitative study using a correlational study with a cross sectional approach. The research was conducted at the Elderly Clinic of Sukodadi Community Health Center, Lamongan District in March-June 2018.

The population in the study were all elderly who went to the Elderly Clinic of Sukodadi
Community Health Center, Lamongan District in March-June 2018, so a research sample of 47 respondents was obtained. The sampling technique used was consecutive sampling, by adjusting the inclusion criteria. The inclusion criteria in this study were the elderly, both male and female, aged over 60 years and able to communicate, not necessarily being able to read and write, but able to understand and answer the researcher's questions.

Measurement of mental status using SPMSQ according to Pfeiffer, which consists of 10 questions to detect: orientation, personal history, long-term memory and mathematical abilities (Lueckenotte, 2013). The interpretation of the mental status assessment is as follows: error 0-2, intact intellectual function, 3-4 errors, minor intellectual damage, 5-7 errors, medium intellectual damage and error 8-10, severe intellectual damage, which are defined as variables independent. The measurement of the ability of social interaction uses a questionnaire with parameters of social interaction, including: cooperation, competition, fighting and accommodation (Soekanto, 2015). The questionnaire consists of 20 questions, in the form of a Likert scale with an assessment score of 1-4 for each answer. Determination of categories based on the percentage with the provisions: less social interaction capacity $<55 \%$, moderate social interaction capacity $56-75 \%$, and good social interaction capacity $76-100 \%$.

This study tested the validity and reliability of the social interaction ability instrument. The results of the validity test, as many as 20 questions were declared valid because the coefficient values ranged from 0.518 to 0.647 , while the reliability test using the alpha test formula obtained the alpha coefficient value 0.882 , so the instrument was declared reliable.

Data collection was carried out by the researcher himself by visiting the respondents one by one, with the researcher-guided filling technique, if the respondent could speak Indonesian they could immediately fill in the questionnaire, but if the respondent did not speak Indonesian, the researcher would help guide by translating the questions into Javanese. The method of distributing the questionnaires was done by first checking mental status using SPMSQ, then distributing social interaction ability questionnaires. Data analysis used the Spearman test with a significance level of $p<0.05$. 


\section{RESULTS}

Table 1 Characteristics of the Elderly at Sukodadi Community Health Center, Lamongan District March-June $2018(n=47)$

\begin{tabular}{cccc}
\hline No & Characteristics & Frequency & Percentage \\
\hline 1 & Gender : & & 31,9 \\
Male & 15 & 68,1 \\
2 & Female & 32 & 78,7 \\
& Age : & & 21,3 \\
& $60-74$ years & 37 & 0 \\
3 & $75-90$ years & 10 & 0 \\
& $>90$ years & 0 & 10,6 \\
& Marital Status : & & 89,4 \\
& Not married & 0 & \\
& Married & 5 & 59,6 \\
& Widow/Widower & 42 & 34,0 \\
& Education : & & 6,4 \\
\hline
\end{tabular}

The characteristics of respondents which include: gender, age, marital status and education can be seen in table 1 , which shows that the number of female respondents is more than male respondents, with a proportion of $68.1 \%$. The most respondents were $60-74$ years old, namely $78.7 \%$, with the largest marital status being widows / widowers at $89.4 \%$. Most of the respondents did not go to school, namely $59.6 \%$ and only $6.4 \%$ of the respondents had formal junior high school.

Table 2 Distribution of Elderly Mental Status at Sukodadi Community Health Center, Lamongan District March-June 2018 ( $n=47$ )

\begin{tabular}{cccc}
\hline No & Mental Status & Frequency & Percentage \\
\hline 1 & Intact Intellectual Function & 18 & 38,3 \\
2 & Minor Intellectual Damage & 21 & 44,7 \\
3 & Medium Intellectual Damage & 8 & 17,0 \\
4 & Severe Intellectual Damage & 0 & 0 \\
\hline & Total & 47 & 100 \\
\hline
\end{tabular}

The detailed mental status of respondents can be seen in table 2, which shows that most of the respondents experienced minor intellectual damage (44.7\%) and only a small proportion who experienced medium intellectual damage $(17,0 \%)$.

Table 3 Distribution of Elderly Form Social Interaction Capacity at Sukodadi Community Health Center, Lamongan District March-June $2018(n=47)$

\begin{tabular}{ccccc}
\hline No & \multirow{2}{*}{ Forms of Social Interaction } & $\begin{array}{c}\text { Category } \\
\text { Social interaction }\end{array}$ & Frequency & Percentage \\
\hline 1 & Cooperation & Good & 8 & 17,0 \\
& & Moderate & 26 & 55,3 \\
2 & Less & Good & 13 & 27,3 \\
& \multirow{2}{*}{ Competition } & Moderate & 11 & 23,4 \\
3 & \multirow{3}{*}{ Fighting } & Less & 25 & 23,2 \\
& & Good & 11 & 19,1 \\
4 & Accommodation & Moderate & 21 & 44,7 \\
& & Less & 17 & 36,2 \\
& & Good & 9 & 19,1 \\
\end{tabular}


The social interaction ability of the elderly in general, from the 4 forms of social interaction, most of the respondents have social interaction skills in the medium category. The description for each form of social interaction can be explained as follows, namely: most respondents have the ability to cooperate in the medium category, namely $55.3 \%$, and only a small proportion of respondents have good cooperation skills, namely $27.7 \%$, while the ability of social interaction In the form of competition, most respondents have the ability in the medium category, namely $53.2 \%$, and the rest have the same distribution of respondents who have poor and good competitiveness, namely $23.4 \%$ respectively. The ability of elderly social interaction in the form of disputes, most of the respondents have the ability in the medium category, namely $44.7 \%$, and only a small proportion have good abilities, namely $36.2 \%$, while the ability of elderly social interactions in the form of accommodation, most respondents have ability in the medium category is $61.7 \%$, and the rest is the same distribution of respondents who have poor and good accommodation capabilities, namely $19.1 \%$ respectively. In general, the social interaction abilities of the elderly from 4 forms of social interaction can be described as follows:

Table 4 Distribution of Elderly Social Interaction Capacity at Sukodadi Community Health Center, Lamongan District March-June $2018(n=47)$

\begin{tabular}{cccc}
\hline No & Social Interaction Capacity & Frequency & Percentage \\
\hline 1 & Less Social Interaction Capacity & 8 & 17,0 \\
2 & Moderate Social Interaction Capacity & 24 & 51,1 \\
3 & Good Social Interaction Capacity & 15 & 31,9 \\
\hline & Total & 47 & 100 \\
\hline
\end{tabular}

Shows that most of the respondents have the social interaction ability in the medium category, namely $51.1 \%$, while only a small proportion of respondents have less social interaction ability, namely with the proportion of $17.0 \%$.

Table 5 Crosstab Mental Status and Social Interaction Capacity at Sukodadi Community Health Center, Lamongan District March-June $2018(\mathrm{n}=47)$

\begin{tabular}{|c|c|c|c|c|c|c|c|c|c|c|}
\hline \multirow{3}{*}{ Mental Status } & \multicolumn{8}{|c|}{ Social Interaction Capacity } & \multirow{3}{*}{$\mathbf{p}$} & \multirow{3}{*}{$\mathbf{r}$} \\
\hline & \multicolumn{2}{|c|}{ Good } & \multicolumn{2}{|c|}{ Moderate } & \multicolumn{2}{|c|}{ Less } & \multicolumn{2}{|c|}{ Total } & & \\
\hline & $\mathbf{n}$ & $\%$ & $\mathbf{n}$ & $\%$ & $\mathbf{n}$ & $\%$ & $\mathbf{n}$ & $\%$ & & \\
\hline Intact Intellectual Function & 1 & 5,6 & 17 & 94,4 & 0 & 0 & 18 & 100 & 0,024 & 0,328 \\
\hline Minor Intellectual Damage & 14 & 66,7 & 7 & 33,3 & 0 & 0 & 21 & 100 & & \\
\hline Medium Intellectual Damage & 0 & 0 & 0 & 0 & 8 & 100 & 8 & 100 & & \\
\hline Severe Intellectual Damage & 0 & 0 & 0 & 0 & 0 & 0 & 0 & 0 & & \\
\hline
\end{tabular}

Shows that almost all elderly with normal mental status have moderate social interaction ability (94.4\%), most elderly with mild intellectual impairment have good social interaction skills (66.7\%), and all elderly with moderate intellectual impairment have lack of social interaction skills (100\%). The Spearman test results obtained $p=0.024$ and $r=0.328$, so that $p<0.05$, then $\mathrm{Ha}$, is accepted, meaning that there is a relationship between mental status and social interaction skills in the elderly. Meanwhile, when viewed from the results of $r$ count of 0.328 , it shows that the strength of the correlation is moderate and the direction of the correlation is positive because the value of $r$ count $<0.5$.

\section{DISCUSSION}

Mental Status, the results of this study are influenced by the age of the majority of respondents aged 60-74 years old, so it shows that the older the respondent is, the higher the risk of mental status disorders, because the age factor plays a role in determining the respondent's mental status. Healthy elderly without vascular disease, age can affect no more than 0.1 mental status examination scores in each year (Heisz et al., 2015). This is reinforced by Husmiati (2016), that the older the age, the ability to test mental and cognitive function decreases. However, this is not entirely true, because at the age of 65-75 years there is a decline in some abilities with a wide difference between individuals and there is more decline in certain types of abilities at the age above 80 years.

Most of the respondents are women, in which women have a higher risk of cognitive dysfunction than men. According to Meyer, Castro-Schilo and Aguilar-Gaxiola ( 2014), there is 
an effect of gender on mental status. The results of his study found that elderly who are less than 80 years old, the incidence of dementia that occurs is more in the group of women than men. This situation is because the life expectancy of women is higher than that of men, so that the elderly population of women is more than men. The estrogen hormone factor is thought to be involved in regulating several non-reproductive functions, including: learning and memory functions, affective and emotional status, motor coordination and pain sensitivity. Some postmenopausal women have difficulty remembering important names and information and there is decreased fine motor coordination and feelings of anxiety and depression. This effect shows that estrogen acts on several areas in the brain outside the hypothalamus, including: the hippocampus, cerebellum, basal forebrain and brain stem, and even some neurotransmitter systems in the brain (Rautio, Heikkinen and Heikkinen, 2015).

The results also showed that most respondents who did not go to school experienced mental status disorders. According to Atkinson et al. (2015), education has a direct effect on the structure and capacity of the brain, increases the number of synapses and vascularization of blood to the brain, so that it will also affect one's performance in mental status tests. This result is supported by Starr et al. (2012), that men tend to have a higher total mental status score than women. This difference in score is due to differences in the attainment of a person's educational level, namely that men tend to have a higher level of education than women, so that with an ongoing educational process, individuals tend to have the ability to test mental status.

Respondents, $89.4 \%$ of whom were widows/ widowers, had a higher risk of mental status decline compared to those who were married. According to Atkinson et al. (2015), someone who has never been married and has no partner has a greater risk of mental status disorders than respondents who are married and have a partner. A person who is not married or has no partner tends to feel lonely in his old age compared to someone who has a partner, because in general they do not have someone who can help in conditions of stress and depression, so this has an impact on their mental status. Efforts to overcome this loneliness, they tend to participate in society to carry out social activities, although this also depends on the opportunity and their health conditions.

Social Interaction Capacity, the results showed that the social interaction skills of the elderly in the form of cooperation, competition, fighting and accommodation were mostly in the medium category, this meant that the elderly were able to create good social situations and were able to create an effective communication system.

Social situations can occur, if there is a relationship between humans and one another, through 2 stages, namely: a situation of togetherness and a situation of social groups. The way the elderly conduct social interactions also determines the communication methods used. The factors for fostering good interpersonal relationships are: a sense of trust, a sportsmanship attitude and an open attitude (Damaiyanti, 2013).

According to Soekanto, (2015), there are many variations in social interaction, the more it will create benefits in social situations. The benefits include: awareness of common interests, coordination of various different personalities, cooperation between social groups, producing new patterns in problem solving, and increasing group solidarity.

In general, the social interaction skills of the elderly can be seen in table 4 , which shows that most of the elderly have extensive social interaction. According to Damaiyanti, (2013), almost all elderly people have good social interaction with their family and neighbors, only $2.6 \%$ admit that their relationship with their family is not good. Harmonious social interaction with family and the environment is everyone's dream. This harmonious situation will be achieved if individuals can create it themselves or are able to adapt themselves to their environment in a harmonious and balanced manner (Bungin, 2011). The ability of elderly social interactions also depends on their efforts to adapt to their environment, because social interaction can occur if it meets two conditions, namely communication and social contact (Soekanto, 2015).

Relationship Mental Status and Social Interaction Capacity, According to Zunzunegui et al. (2013), the effect of physical activity including the social interaction of the elderly on several components of mental status examination, it was found that regular physical activity can have a reciprocal effect on mental status, especially the speed of processing information received. This is reinforced by Bassuk, Glass and Berkman (2012), who also stated that the elderly group who actively participates and has good social interactions such as eye contact and has an emotional attachment to close friends or takes part in responding to a situation casually without stress, will still have a good mental status. Meanwhile, the elderly who are unable to adapt to social changes will cause stress reactions, starting with increased production of glucocorticoid and 
this has implications for the hippocampus and gradually affects their mental status.

According to Hurlock (2012), in carrying out social interactions, the elderly experience many obstacles because of health problems and decreased income after retirement, as a result they are forced to resign from social activities. This resignation resulted in little social networking. This social network effect is influenced by mental status which can affect, including: physical activity, social activity, cognitive stimulation activity, the presence of depressive symptoms and several accompanying chronic diseases. According to Zunzunegui et al. (2013), the difficulty of the elderly in maintaining friendship is greatly influenced by their mental status. This difficulty is due to the weak body condition so it is difficult to visit friends, friends who have died or moved far away. It is predicted that a decrease in mental status in the elderly will cause less social relationships, reduced participation in social activities and a lack of social attachment.

\section{CONCLUSION}

The conclusion of this study is that most of the elderly (44.7\%) have mild intellectual impairment, most of the elderly (51.1\%) have moderate social interaction skills, and there is a relationship between mental status and social interaction skills in the elderly with a strong correlation. moderate and the direction of the correlation is positive.

\section{REFERENCES}

Atkinson, H. H. et al. (2015) 'Predictors of combined cognitive and physical decline', Journal of the American Geriatrics Society, 53(7), pp. 1197-1202. doi: 10.1111/j.15325415.2005.53362.x.

Bassuk, S. S., Glass, T. A. and Berkman, L. F. (2012) 'Social Disengagement And Incident Cognitive Decline In CommunityDwelling Elderly Person', Annals of Internal Medicine, 131(3), pp. 165-173. doi: $\quad 10.7326 / 0003-4819-131-3-$ 199908030-00002.

Bungin, B. (2011) Sosiologi Komunikasi: Teori, Paradigma, dan Diskursus Teknologi Komunikasi di Masyarakat. Jakarta : Kencana Prenada Media Group.

Damaiyanti, M. (2013) Komunikasi Terapeutik Dalam Praktik Keperawatan. Bandung: Refika Aditama.

Depkes RI (2010) Pedoman Pembinaan Kesehatan Usia Lanjut: Kebijaksanaan Program. Jakarta: Direktorat Bina Kesehatan Keluarga.
Gallo, R. et al. (2012) Buku Saku Gerontologi. Ed. Revisi. Jakarta: EGC.

Heisz, J. J. et al. (2015) 'Age Differences In the Association of Physical Activity, Sociocognitive Engagement, and TV Viewing on Face Memory', Health Psychology, 34(1), pp. 83-88. doi: 10.1037/hea0000046.

Hurlock, E. B. (2012) Psikologi Perkembangan Suatu Pendekatan Sepanjang Rentang Kehidupan. Edisi Baru. Jakarta : Erlangga.

Husmiati, H. (2016) 'Demensia pada Lanjut Usia dan Intervensi Sosial', Sosio Informa, 2(3). doi: 10.33007/inf.v2i3.839.

Kaplan, H. I., Sadock, B. J. and Grebb, J. A. (2014) Sinopsis psikiatri: IImu Pengetahuan Perilaku Psikiatri Klinis. Ed. Revisi. Jakarta : Bina Rupa Aksara.

Lueckenotte, A. (2013) Pengkajian Gerontologi. Edisi 3. Jakarta: EGC.

Meyer, O. L., Castro-Schilo, L. and Aguilar-Gaxiola, S. (2014) 'Determinants of Mental Health and Self-rated Health: A model of socioeconomic status, neighborhood safety, and physical activity', American Journal of Public Health, 104(9), pp. 17341741. doi: 10.2105/AJPH.2014.302003.

Muhith, A. and Siyoto, S. (2016) Pendidikan Keperawatan Gerontik. Edisi I. Yogyakarta: CV. Andi Offset (Penerbit Andi).

Rautio, N., Heikkinen, E. and Heikkinen, R. L. (2015) 'The association of socio-economic factors with physical and mental capacity in elderly men and women', Archives of Gerontology and Geriatrics, 33(2), pp. 163-178. doi: 10.1016/S01674943(01)00180-7.

Soekanto, S. (2015) Sosiologi Suatu Pengantar. Edisi Baru. Jakarta: PT. Raja Grafindo Persada.

Stanley, M. (2012) Buku Ajar Keperawatan Gerontik. Edisi 3. Jakarta : EGC.

Starr, J. M. et al. (2012) 'Age-associated cognitive decline in healthy old people', Age and Ageing, 36(4), pp. 295-300. doi: 10.1093/ageing/26.4.295.

Wilianarti, P. F. (2018) Buku Ajar Lansia : Lanjut Usia Perspektif dan Masalah. Surabaya: UM Surabaya Publishing.

Zunzunegui, M. V. et al. (2013) 'Social Network, Special Integration And Social Engagement Determine Cognitive Decline In Community-Dwelling Spanish Older Adults', Journals of Gerontology Series B Psychological Sciences and Social Sciences, 58(2). doi: 10.1093/geronb/58.2.593. 